\title{
Equity Pledge and Innovation Performance
}

\author{
Grouping Research Based On Equity Structure
}

\author{
Zhiwu Xiao*, Mengqiu Lu \\ School of Economic and Management, Jiangxi University of \\ Science and Technology \\ Ganzhou, 341000, China \\ zxcdf39772008@qq.com
}

\author{
Ligang Liu \\ School of Economic and Management, Jiangxi University of \\ Science and Technology \\ Ganzhou, 341000, China \\ 250187106@qq.com
}

\begin{abstract}
Innovation transformation, as a major issue for Chinese enterprises at present, is a key issue that the China continues to pay attention to and attach importance to. This paper tries to take the individual behavior-equity pledge as an entry point, pays attention to the impact of shareholder's equity pledge on the investment of enterprise research and development after the equity pledge, and also examines how the impact of equity pledge on enterprise research and development investment is different under different equity structures. In this paper, the A-share manufacturing listed companies were selected for 20142018 as a research sample, the empirical research are carried out by the method of multiple linear regression. It is found that equity pledge has a negative impact on the research and development of enterprises, compared with non-state-owned enterprises, the r\&d investment of state-owned enterprises is more affected by equity pledge, and If the enterprise's equity concentration is higher, the less its research and development investment is affected by the equity pledge.
\end{abstract}

Keywords-Innovation transformation; equity pledge; ownership structure; $r \& d$ investment

\section{INTRODUCTION}

In recent years, Chinese enterprises attach increasing importance to research and development to maintain a strong competitiveness. Independent research and development capabilities are also improving, but the overall innovation performance or innovation output of enterprises has not significantly improved. More realistic situation is that the current equity pledge, this financing method will affect the investment management decision of enterprise, research and development as an important part of the enterprise investment decision-making will certainly be affected by it, and may bring some negative pressure to the enterprise's innovation performance.

Although equity pledge is the individual behavior of shareholders, but in our country, it is not to be ignored that the phenomenon of "one big" is more common, and equity pledge will also cause moral hazard, also likely to distort the company's governance mechanism, and then have a negative impact on the company's performance and innovation and development. Zhou Chenxi believes that the controlling shareholders of the enterprise play a central role in the decision-making process of whether to support innovation within the enterprise[1].Zhang Ruijun et al think that after the controlling shareholder's equity pledge, the company's agency problem will become more serious, and the higher the pledge ratio, the more serious the agency problem[2]. Wang Fen believes that controlling shareholders of equity pledges will take the performance of the company's shares in the capital markets very seriously, as the collapse in share prices puts them at risk of a transfer of control, so they tend to adopt a more conservative and robust corporate strategy[3].Therefore, the individual behavior of controlling shareholder's equity pledge will indeed have a profound impact on the innovation research and development decision of the enterprise.

Most of the conclusions about the impact of equity structure on enterprise innovation performance are different. Some scholars believe that state-owned enterprises are not conducive to investment in research and development innovation, they believe that non-state-owned enterprises in the search for lasting competitiveness and attach importance to research and development investment, in contrast, state-owned enterprises because of the special status of the background of the lack of sustained innovation momentum. Another part of the scholars think that state-owned enterprises because of the natural advantages of political resources, capital strength lead to higher investment in research and development, outstanding innovation performance, and the impact of equity concentration on innovation is not the same conclusion. In conclusion, regarding the influence of equity structure on research and development investment, the results of literature research have not been unified, so it is necessary to carry out further empirical analysis in this respect.

In this article, we want to study whether such individual behavior of controlling shareholders will have an impact on the research and development decisions of the pledged enterprises in the case of such a large-scale and high frequency of equity pledge in the capital market, and how does the impact of the pledge ratio on the innovation performance of enterprises? As the foundation of corporate governance, What role does the equity structure which contains the nature of stock rights and the concentration of equity play in the relationship between equity pledge and $\mathrm{r} \& \mathrm{~d}$ ?

The contributions of this paper mainly include the following aspects: First, This paper enriches the study of factors that affect enterprise innovation. The current research on the influence factors of enterprise innovation is mostly 
focused on the macro-level tax policy, financing environment, the degree of marketization and the micro level of corporate governance and so on. Equity pledge, as the individual behavior of shareholders, relevant research is less. Second, most of the existing research results are concerned about the direct link between equity pledge and $r \& d$ investment, lack of intermediate link research, in this paper in the process of analyzing the impact of equity pledge on the innovation performance of enterprises, the equity structure into the analysis framework specific research equity pledge impact on the enterprise's innovation performance path, The "black box" of this research dimension was uncovered.

In the normative research, this paper mainly uses the literature research method, deductive method to carry out theoretical analysis and research hypothesis deduction. On the basis of collecting, combing and analyzing the literatures on the influence factors of enterprise innovation performance, the equity pledge of controlling shareholders and the economic consequences of equity structure, the theoretical contents such as the principal-agent theory, signal transmission theory and innovation theory are expounded as the theoretical basis of this paper.

In empirical research, this paper selects the A-share manufacturing company listed in Shenzhen and Shanghai between 2014 and 2018 as our sample. Using the method of multiple linear regression measurement to test the hypothesis put forward by this paper.

The research ideas framework of this paper is as follows

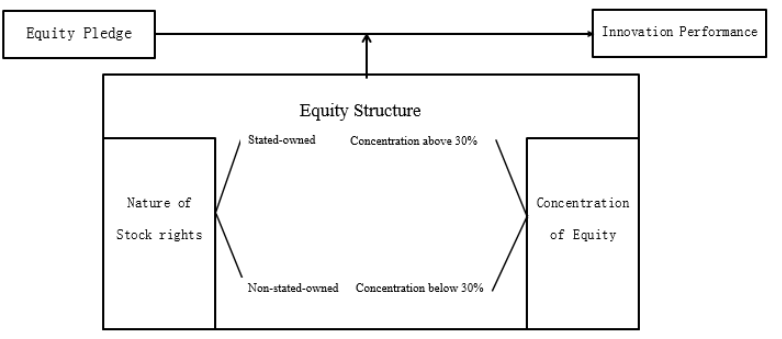

Fig. 1

\section{LITERATURE REVIEW}

\section{A. The Impact of Equity Pledge on Innovation Performance}

China's capital market is particularly serious, the academic research on how the existence of controlling shareholders influence the development of a company is a lot. As an important link affecting the development of the company, research and development has the characteristics of long-term, high investment, high risk, high return and so on, the success of research and development can bring great profits to the company's long-term survival, and the failure of innovation will also cause huge losses, resulting in stock price fluctuations. In the meantime, many corporates are struggling for the situation of equity pledge, in this case, the controlling shareholder in order not to lose control of the company, there is likely to be short-sighted, risk aversion situation, which will lead to enterprises more cautious in research and development investment or even abandon the enterprise innovation in favor of the short-term behavior of investing funds in sound projects.
Although equity pledge is the individual behavior of shareholders, however, the majority shareholder status of listed companies is special, and its personal behavior is likely to affect the company's business decision-making. Although the phenomenon of controlling shareholder's equity pledge has occurred both at home and abroad, the research on the economic consequences of controlling shareholder's equity pledge is not rich, most of the literature focuses on the company's performance, and few research focuses on the impact of the innovation performance of enterprises. So there is still some research gap in the specific path transmitted to the enterprise's innovation performance. Therefore, it is of practical significance to study how the behavior of controlling shareholders to carry out equity pledge affects the innovation performance of enterprises.

\section{B. The Influence of Equity Structure on the Relationship between Equity Pledge and Innovation Performance}

Whether controlling shareholders have more positive or more negative impact on the company's development also involves the issue of corporate governance structure, LaPorta et al. (2000) believe that good corporate governance can reduce the behavior caused by internal agency problems that undermine the value of the company. In the aspect of enterprise innovation, there are many studies to prove the positive role of corporate governance. As the basis of corporate governance, the different equity structure design will inevitably influence the behavior tendency of shareholders and managers by influencing the internal governance mechanism, thus influencing the decision-making of managers and the company's innovative performance.

Regarding the nature of stock rights and innovation performance, Wang's research holds that in state-owned holding companies, managers are vulnerable to various constraints in the company and do not have absolute decisionmaking power, coupled with the fact that managers are mostly administrative appointments, and hope that the company's business development can be stable during the in-service period. Therefore, more committed to achieving the national set political goals and short-term performance, abandoning the investment in high-risk innovative research and development projects. Federico selected nearly a thousand listed companies in Europe as research samples and empirical research found that non-state-owned holding companies have a high investment in research and development [4]. Through empirical research, Ren Haiyun found that the nature of state-owned holding has a significant negative effect on the company's innovation and research and development investment and performance [5]. Tang Yeguo selected the domestic listed companies as a research sample, after empirical analysis to draw the same conclusion: the company's actual control in the hands of the state, management is committed to the company's stable production and management, in order to obtain more short-term benefits, reduce high-risk innovative research and development projects[6].Other researchers have opposite views, Li Chuntao, Song Min came up with a different point of view from the point of view of resource allocation, state-owned enterprises have a natural connection with the government, have stronger financing capacity, better technical conditions, 
and thus can maintain a higher level of research and development input, which is conducive to the innovation output of enterprises, the innovation performance of enterprises is excellent[7].

Research on the relationship between equity concentration and innovation, scholars at home and abroad have not yet reached a unanimous conclusion. Yang Jianjun et al introduced the psychological factors of risk aversion into the model, found that the more concentrated the equity, the weaker the tolerance of risk, the less investment in research and development, which is not conducive to the innovation performance of enterprises[8]. From the perspective of agency theory, there is a conflict of interest between controlling shareholders and small shareholders, when the concentration of equity is high, the controlling shareholders often try to control the minority shareholders, abuse the company's resources, at the expense of the interests of small shareholders. At the same time, controlling shareholders tend to appoint relatives and friends as senior managers, controlling shareholders can easily engage in self-interested transactions within the enterprise at a lower cost, transfer resources out of the enterprise, in order to maximize short-term benefits without focusing on the long-term benefits of the enterprise research and development innovation. Wang Huacheng believes that the high concentrated equity has a negative impact on the intensity of investment in r\&d[9]. Suk Bong Choi etal found that in emerging economies, the controlling shareholders of the equity-focused enterprises are more inclined to make immediate interests when making decisions, ignoring the importance of technological innovation [10]. Some scholars have come to different conclusions from different angles. Deng $\mathrm{Z}$ 、 Peter $\mathrm{H}$ believed that equity concentration can play a role in alleviating the agency conflict between management and shareholders, and stable equity design can make the company's investment behavior have long-term characteristics[11]. Baysinger also had different conclusions, he believes that in the high concentration of equity enterprises, the controlling shareholders have more motivation to supervise the enterprise's business decision-making, grasp more comprehensive information, so that we can work out a long-term plan conducive to enterprise development, reduce the short-term performance pressure of managers, is conducive to increasing long-term research and development investment activities [12]

\section{Review of Literature}

Through the combing of the above literature, the research on the impact of equity pledge and equity structure on enterprise innovation is based on innovation theory, principalagent theory and signal transmission theory to explore the influence between each other. On the relationship between equity pledge and enterprise innovation, the existing literature has reached a more consistent conclusion, and holds that equity pledge has a negative impact on enterprise innovation. But the impact of equity structure on innovation is not uniform among scholars. On the one hand, the large shareholder's equity pledge aggravates the problem of principal-agent; on the other hand, it sends a dangerous signal to the market, which is likely to have a negative impact on the innovation of enterprises. The nature and shareholding ratio of the major shareholders will have an important impact on the innovation of enterprises, but the conclusions are not uniform, and the majority shareholders may promote the innovation of enterprises or hinder the innovation of enterprises. The state-owned nature and the nonstate-owned nature are different because of the difference between the two business objectives and the operating environment. The high concentration of equity in the company may may cause large shareholder's "empty behavior " and small and medium-sized shareholders "free-riding" phenomenon, which will adversely affect innovation. The less concentrated equity may cause conflicts between shareholders and affects the efficiency of the company's decision-making.

\section{HYPOTHESIS}

Analysis from the surface, Equity pledge is a simple individual behavior of shareholders, which is not directly related to listed companies. However, after the equity pledge, the controlling shareholder still enjoys the control and decision-making power of the company, and the risk of the equity pledge is bound to have an impact on the company's overall business performance and innovation input by influencing the shareholder's business decision-making and investment and financing behavior preference. Zhang Ruijun believe that the equity pledge suggests shareholders facing a strong capital needs, expressing a signal that shareholders have financial difficulties. According to the signal transmission theory, because the equity pledge releases the information that the shareholders face the capital gap and the funds are illiquid, the investor may over interpret the information after receiving the pledge announcement, which in turn affects the investor's confidence and can easily cause stock price fluctuations. And once the share price falls and the value of the shares hits the line or closes the position, the controlling shareholder is in danger of losing control. Moreover, equity pledge will also lead to the moral hazard of shareholders, the controlling shareholders based on the maximization of personal interests, it is very easy to use its special status in the listed company to encroach on the interests of other shareholders, aggravating the second type of agency problem. Shareholder stake pledge will also enhance the shareholder's risk aversion degree, weaken the shareholder's risk-taking ability, and then this kind of risk aversion may be reflected in other behavior decisions. As a high-risk investment, innovative research and development, coupled with its long investment period, information asymmetry problem is serious, the benefits lag and so on, the investment results are difficult to reflect in the short-term operating performance. The controlling shareholder is bound to avoid the risky research and development investment project out of fear of the transfer of control. Based on this, we present hypothesis 1 of this article.

H1: Equity pledge is negatively correlated with enterprise innovation performance.

In the case of equity dispersion, the small shareholders because of the limited holding of shares, lack of motivation and ability to restrain and supervise the behavior of the manager, resulting in the phenomenon of "free ride" between shareholders. And in a company with a high concentration of equity, the controlling shareholder is prone to "emptying" the company's behavior, at this time other shareholders are difficult 
to play the role of checks and balances, it is difficult to stop the controlling shareholders to their interests, some shareholders are likely to "vote with their feet", sell the company's shares, which affects the company's share price, Risk of closing a position in the case of equity pledge. When the company's equity structure is in a relatively decentralized state, when a shareholder carries out equity pledge, other shareholders anticipate the risk and have the ability and the power to join force to intervene and restrain it, or take the same equity pledge behavior to force the shareholders to stop the dangerous equity pledge behavior, thereby reducing the risk of equity pledge to the company. When the company's overall risk is low, it is beneficial for managers to make investment decisions that support research and development innovation.

$\mathrm{H} 2$ : The higher the concentration of equity, the greater the negative impact of equity pledge on research and development investment.

This paper selects and the concentration of equity to represent the equity structure, and the impact of on the investment of enterprise research and development in previous studies has been discussed centrally, but no consistent conclusion has been reached. Because of the difference of nature of stock rights, there is bound to be differences in the impact of enterprise innovation performance. The nature of enterprises is different, their pursuit of goals and interests are also different, In this paper, simply divided into state-owned enterprises and non-state-owned enterprises. Under China's special economic system, there are a large number of stateowned enterprises in China's listed enterprises, some studies show that in state-controlled enterprises, because of their special status has a natural advantage, on the one hand, Shareholders to carry out equity pledge needs to be reported to SASAC, on the other hand, even if some equity pledge has touched the closing line, SASAC generally will not agree to close the position, but also more through supplementary pledge, cash and other ways to eliminate risks. In this way, the risk of equity pledge of state-owned enterprises is overall controllable, and the worst results are also the government intervention, coupled with the research and development funds of the state support, the investment in research and development and enterprise innovation performance has less impact. Non-state-owned enterprises such as private enterprises or foreign-funded enterprises tend to be relatively small in size, limited access to bank loans, and the lack of timely access to information resources, lack of implicit government guarantees and other innate disadvantages lead to shareholders to carry out equity pledge will distort the normal business investment decisions of enterprises, In particular, high-risk innovative research and development projects are more likely to take a negative attitude, will significantly affect research and development investment and innovation performance results. Based on this, the second hypothesis of this article is derived.

H3: Compared with state-owned enterprises, equity pledge has a greater negative impact on the innovation performance of enterprises in non-state-owned enterprises.

\section{DATA AND METHODS}

\section{A. Sample selection and data sources}

In order to verify the three assumptions put forward in this paper, it is proposed to establish a multiple linear regression model for testing. The sample of this paper is the A-share manufacturing company listed in Shenzhen and Shanghai between 2014 and 2018. The reason why all industries are not selected listed companies, taking into account the general industry innovation activities are less, and the study of manufacturing listed companies innovation activities for the relevant departments to formulate policies is also more reference value. For the initial data, we processed the following: (1) Excluding samples that have been on the market for less than one year; (2) Exclude listed companies that have not traded normally in the current year; (3) Exclude samples of missing related variables. (4) Finally, the data is translated into balanced panel data, leaving 652 companies with a total of 3,260 data in the sample.

\section{B. Introducton of variables}

Referring to previous studies, this paper uses R\&D to measure the innovation performance of enterprises. The amount of R\&D investment often reflects the importance that an enterprise attaches to innovation. The higher the indicator value represents the more enterprise innovation activities. In the aspect of equity pledge, we use the equity pledge ratio to show that the high ratio of equity pledge indicates that the probability of capital shortage is very large. In this paper, the concentration of equity and the nature of stock rights are selected to study how the equity structure affects the relationship between equity pledge and innovation performance, and this paper use the shareholding ratio of the largest shareholder to represent the concentration of equity, and simply divided the nature of stock rights into state-owned and non-state-owned enterprises. Considering that the research and development investment of enterprises is influenced by other factors, this paper, while determining the annual virtual variables, selects the enterprise size, enterprise age, assetliability ratio, total asset turnover rate, ROA, government subsidy, operating net cash flow as the control variables. All data comes from the Wind database, and the corresponding information for each variable is shown in Table I. 
TABLE I : INFORMATIONS OF VARIABLES

\begin{tabular}{|c|c|c|c|}
\hline Type & variables & symbol & Interpretation \\
\hline $\begin{array}{l}\text { dependent } \\
\text { variable }\end{array}$ & $\begin{array}{l}\text { Research and } \\
\text { development }\end{array}$ & $\mathrm{RD}$ & $\begin{array}{l}\text { Ratio of the company's } \\
\text { research and development } \\
\text { expenditure to total assets at } \\
\text { the end of the year }\end{array}$ \\
\hline $\begin{array}{l}\text { independent } \\
\text { variables }\end{array}$ & $\begin{array}{l}\text { Equity pledge } \\
\text { ratio }\end{array}$ & Pledge & $\begin{array}{c}\text { Percentage of equity pledge } \\
\text { by controlling shareholders } \\
\text { in the current year }\end{array}$ \\
\hline \multirow{7}{*}{$\begin{array}{c}\text { Control } \\
\text { variables }\end{array}$} & $\begin{array}{l}\text { Size of } \\
\text { company }\end{array}$ & Size & $\begin{array}{l}\text { Natural nods to total assets } \\
\text { at the end of the period }\end{array}$ \\
\hline & $\begin{array}{l}\text { Ages of } \\
\text { company }\end{array}$ & Age & $\begin{array}{l}\text { Calculated from the year the } \\
\text { company was founded }\end{array}$ \\
\hline & $\begin{array}{c}\text { Liability on } \\
\text { asset ratio }\end{array}$ & Debt & Total liabilities/total assets \\
\hline & Asset turnover & Turn & $\begin{array}{l}\text { Operating income / total } \\
\text { assets }\end{array}$ \\
\hline & $\begin{array}{l}\text { Return on } \\
\text { Assets }\end{array}$ & Roa & Net profit/total assets \\
\hline & $\begin{array}{l}\text { Government } \\
\text { funding }\end{array}$ & Govsub & $\begin{array}{l}\text { Total amount of government } \\
\text { funding over a year }\end{array}$ \\
\hline & $\begin{array}{l}\text { Net cash flow } \\
\text { from operations }\end{array}$ & Cflow & $\begin{array}{c}\text { The ratio of net cash flow } \\
\text { from operating activities to } \\
\text { total assets in the current } \\
\text { year }\end{array}$ \\
\hline \multirow{2}{*}{$\begin{array}{l}\text { Grouping } \\
\text { variables }\end{array}$} & $\begin{array}{c}\text { Nature of stock } \\
\text { right }\end{array}$ & Soe & $\begin{array}{l}\text { If the enterprise is a state- } \\
\text { owned enterprise, the value } \\
\text { is } 1 \text {, otherwise the value is } 0\end{array}$ \\
\hline & $\begin{array}{l}\text { Concentration } \\
\text { of equity }\end{array}$ & Top1 & $\begin{array}{l}\text { Shareholding ratio of the } \\
\text { largest shareholder }\end{array}$ \\
\hline
\end{tabular}

\section{Model setting}

In this paper, research and development investment is used as dependent variable, the equity pledge ratio as an independent variable, $\mathrm{X}_{\mathrm{i}}$ represents the control variables.Data of company size, government funding, net cash flow in operations are logarithmic treated, the main model to test the hypothesis is as follows.

Model : $r d=\beta_{0}+\beta_{1}$ Pledge $_{\mathrm{i}, t}+\beta_{\mathrm{i}} \mathrm{X}_{\mathrm{i}, \mathrm{t}}+\sum$ Year $+\delta$

With equity concentration equal to $30 \%$ as the demarcation point, the sample enterprises are divided into two groups, and the regression results are compared and analyzed to test $\mathrm{H} 2$.

According to the nature of equity, the sample enterprises are divided into state-owned enterprises and non-state-owned enterprises, and the regression results of the two groups are compared and analyzed to test $\mathrm{H} 3$;

\section{EMEPRICIAL ANALYSIS}

\section{A. Descriptive statistics of the Main Variables}

The descriptive statistical results of the main variables covered in this article are shown in TABLE II. Statistics show that the average research and development intensity of manufacturing companies in the sample is $4.4 \%$, Compared with developed countries, there is still a certain gap. The average proportion of majority shareholders' equity pledge is $13.2 \%$. The highest pledge ratio is 58.5 per cent and the lowest is 0 , relatively speaking, the pledge ratio is not too
high.However, equity pledge will affect the company's research and development decision-making, worthy of attention. The average turnover rate of the sample manufacturing enterprises is 0.643 , which is at the normal level. On average, the level of debt reached $40.8 \%$, with the highest debt ratio at $86.6 \%$, indicating a higher overall debt ratio. The statistical results of other variables are broadly similar to previous studies, and are not repeated here.

TABLE II : SUMMARY STATISTICS

\begin{tabular}{|l|r|r|r|r|r|r|}
\hline & $\mathrm{N}$ & Mean & St.Dev & min & Median & max \\
\hline rd & 3260 & 0.044 & 0.038 & 0.001 & 0.036 & 0.245 \\
\hline pledge & 3260 & 0.132 & 0.146 & 0 & 0.08 & 0.585 \\
\hline top1 & 3260 & 0.325 & 0.136 & 0.08 & 0.31 & 0.677 \\
\hline age & 3260 & 10.643 & 6.032 & 2 & 8 & 24 \\
\hline roa & 3260 & 0.055 & 0.062 & -0.178 & 0.049 & 0.244 \\
\hline lev & 3260 & 0.408 & 0.187 & 0.06 & 0.401 & 0.866 \\
\hline turn & 3260 & 0.643 & 0.364 & 0.114 & 0.57 & 2.278 \\
\hline lnsize & 3260 & 22.317 & 1.126 & 20.243 & 22.172 & 25.538 \\
\hline lncflow & 2622 & 19.237 & 1.551 & 12.46 & 19.224 & 22.944 \\
\hline lngovsub & 3068 & 15.799 & 2.088 & 6.021 & 16.006 & 20.181 \\
\hline
\end{tabular}

\section{B. Multicollinearity Test}

In order to test the multiple collinearity between variables, this paper does the Pearson correlation test of the main variables, the results are shown in TableIII. From the results, it can be seen that the absolute value of most correlation coefficient between each variable is not more than 0.3 , indicating that there is no multiple collinearity problem, so there is no need to worry about empirical results affected by this problem. From the test results can also be seen, as a key explanatory variable, the proportion of large shareholders equity pledge and research and development investment are negative impact relationship, the correlation coefficient between them is minus 0.043 , which is significant at the $5 \%$ level.at the same time, the concentration of equity, the age of the company, the rate of total assets return, the ratio of assets and liabilities and the ratio of asset turnover are negatively correlated with the investment of research and development. Generally speaking, the total asset return rate and asset turnover should be positively correlated, and their relationship has yet to be further tested.

TABLE III : MATRIX OF CORRELATIONS

\begin{tabular}{|c|c|c|c|c|c|c|c|}
\hline Variables & $(1)$ & $(2)$ & $(3)$ & $(4)$ & $(5)$ & $(6)$ & $(7)$ \\
\hline (1) rd & 1.000 & & & & & & \\
\hline (2) pledge & $-0.043^{* *}$ & 1.000 & & & & & \\
\hline (3) top1 & $-0.115^{* * * *}$ & $-0.097^{* * * *}$ & 1.000 & & & & \\
\hline (4) age & $-0.261^{* * *}$ & $-0.213^{* * *}$ & $0.031^{*}$ & 1.000 & & & \\
\hline (5) roa & $-0.149^{* * *}$ & $-0.037^{* *}$ & $0.140^{* * *}$ & $-0.053^{* * *}$ & 1.000 & & \\
\hline (6) lev & $-0.225^{* * *}$ & $0.031^{*}$ & $0.051^{* * *}$ & $0.331^{* * *}$ & $-0.237^{* * *}$ & 1.000 & \\
\hline (7) turn & $-0.377^{* * * *}$ & $-0.097^{* * * *}$ & $0.169^{* * *}$ & $0.181^{* * *}$ & $0.282^{* * *}$ & $0.158^{* * * *}$ & 1.000 \\
\hline
\end{tabular}

\section{Empirical analysis and results}

Table IV reports the results of the hypothesis-1 test. The first column in TableIV shows that the ratio of equity pledge and the enterprise's research and development investment are 
negatively correlated and significant at the level of $1 \%$, and the results show that for every $1 \%$ increase in the proportion of large shareholders' equity pledge, the research and development investment of enterprises will be affected by about $2.9 \%$; After adding more control variables, the fit of the model improved, and the regression coefficient of the equity pledge ratio was still significant, and the model's interpretation ability was stronger after controlling the time effect. This makes the hypothesis one has been verified, the majority shareholder stake pledge will indeed affect the enterprise's research and development investment, because the shareholders to carry out equity pledge is not likely to be used for the normal operation of the company, but for the company to empty or for other aspects, which will increase the financial constraints of listed companies, increase the risk, In this case, the manager likely to avoid the innovation activities of large and high risk investment.

TABLE IV : H1 TEST

\begin{tabular}{|c|c|c|c|c|c|c|}
\hline \multirow[b]{2}{*}{ Independent: rd } & \multicolumn{2}{|c|}{ (1) } & \multicolumn{2}{|c|}{ (2) } & \multicolumn{2}{|c|}{ (3) } \\
\hline & Coef & $\mathrm{t}$-value & Coef. & t-value & Coef. & $\mathrm{t}$-value \\
\hline pledge & $-0.029 * * *$ & -7.00 & $-0.023 * * *$ & -5.18 & $-0.027 * * *$ & -6.34 \\
\hline age & $-0.001 * * *$ & -11.22 & $-0.001 * * *$ & -8.01 & $-0.001 * * *$ & -9.39 \\
\hline roa & $-0.068 * * *$ & -6.54 & $-0.040 * * *$ & -3.38 & $-0.035 * * *$ & -3.04 \\
\hline lev & $-0.028 * * *$ & -7.87 & $-0.031 * * *$ & -7.17 & $-0.028 * * *$ & -6.64 \\
\hline turn & $-0.031 * * *$ & -17.79 & $-0.026 * * *$ & -14.58 & $-0.027 * * *$ & -14.82 \\
\hline Insize & - & - & 0.000 & -0.39 & $-0.003 * * *$ & -3.07 \\
\hline Incflow & - & - & $-0.001 * *$ & -2.13 & $-0.001 *$ & -1.91 \\
\hline lngovsub & - & - & $0.001 * * *$ & 4.46 & 0.004 *** & 9.35 \\
\hline Constant & $0.096^{* * *}$ & 48.53 & $0.099 * * *$ & 6.91 & $0.113^{* * * *}$ & 7.96 \\
\hline Year & - & & - & & Yes & . \\
\hline Number of obs & 3260 & & 2461 & & 2461 & \\
\hline R-squared & 0.215 & & 0.229 & & 0.257 & \\
\hline
\end{tabular}

In order to test the influence of different equity concentration on the relationship between equity pledge and research and development investment, the difference of equity pledge on research and development investment is compared between the two groups by dividing the sample into two groups to be tested by dividing the equity concentration to $30 \%$ as the demarcation point. Results can be seen in Table V, the number of samples contained in groups with less than $30 \%$ equity concentration is 1121 , and the group with a concentration of more than $30 \%$ contains 1340 samples, and the number of samples between the two groups is not much different. From the results, it can also be seen that in the group with a small concentration of equity, the negative impact of equity pledge on research and development investment is greater, which contradicts the assumption at the beginning of the period. Reasonable explanation in the small concentration of equity in the company, because there is no absolute control of the majority shareholders, will make the decision-making inefficient, the free-riding behavior between shareholders is more serious, will affect the company's research and development investment.
TABLE V : H2 TEST

\begin{tabular}{|c|c|c|c|c|}
\hline \multirow[b]{2}{*}{ Independent: rd } & \multicolumn{2}{|c|}{ Top1<30\% } & \multicolumn{2}{|c|}{ Top1>30\% } \\
\hline & Coef & t-value & Coef. & t-value \\
\hline pledge & $-0.028 * * *$ & -2.94 & $-0.026 * * *$ & -5.00 \\
\hline age & $-0.001 * * *$ & -5.10 & $-0.001 * * *$ & -6.85 \\
\hline roa & $-0.052 * * *$ & -2.75 & $-0.033 * *$ & -2.31 \\
\hline lev & $-0.045^{* * *}$ & -5.30 & $-0.019 * * *$ & -3.48 \\
\hline turn & $-0.037 * * *$ & -8.82 & $-0.019 * * *$ & -10.30 \\
\hline lnsize & $-0.004 * *$ & -2.16 & -0.002 & -1.31 \\
\hline lncflow & 0.000 & -0.27 & $-0.002 * *$ & -2.50 \\
\hline lngovsub & $0.006^{* * *}$ & 7.01 & $0.002 * * *$ & 4.79 \\
\hline Constant & $0.108 * * *$ & 3.68 & $0.112^{* * *}$ & 6.34 \\
\hline Year & Yes & & Yes & \\
\hline Number of obs & 1121 & & 1340 & \\
\hline R-squared & 0.219 & & 0.233 & \\
\hline
\end{tabular}

Similarly, the method of grouping is used to test hypothesis III, and the sample enterprises are divided into state-owned enterprises and non-state-owned enterprises, and the regression results are compared. As can be seen from Table VI, in the state-owned manufacturing enterprises, for every $1 \%$ increase in the proportion of large shareholders' equity pledge, the research and development investment of enterprises should be reduced by $3.4 \%$, while in non-stateowned enterprises, the proportion of equity pledge increases by $1 \%$, and the research and development investment of enterprises should be reduced correspondingly by $2.5 \%$, indicating that in state-owned enterprises, The ratio of equity pledge has a greater negative impact on research and development investment. This is also inconsistent with the assumptions at the beginning of this article, a reasonable explanation may be that in non-state-owned enterprises, because there is no state background of state-owned enterprises, more policy support and more financial support, shareholders and managers are more sensitive to the risks posed by equity pledge, major shareholders worry about the risk of control transfer, Thus, the act of equity pledge itself will have a more cautious attitude, and even if the equity pledge, shareholders will pay more attention to the company's operations and long-term development to prevent the transfer of control, thereby facilitating the company's research and development investment. State-owned enterprises are different, because of its status and background has natural advantages, even if the equity pledge, the binding effect on major shareholders will not be particularly obvious, and do not worry about the risk of equity pledge, because the state-owned enterprises equity involved in state assets, will not be easily closed, which will undoubtedly increase the impact of equity pledge on research and development investment.

TABLEVI : H3 TEST

\begin{tabular}{|c|c|c|c|c|}
\hline & \multicolumn{2}{|c|}{ Soe=1(stated-owned) } & \multicolumn{2}{c|}{ Soe=0(non- stated-owned) } \\
\hline Independent: rd & Coef & t-value & Coef. & t-value \\
\hline pledge & $-0.034^{* * *}$ & -3.00 & $-0.025 * * *$ & -4.07 \\
\hline age & $-0.001 * * *$ & -7.76 & $-0.001 * * *$ & -4.45 \\
\hline roa & -0.015 & -0.77 & $-0.055^{* * *}$ & -3.80 \\
\hline lev & $-0.015^{* *}$ & -2.31 & $-0.039 * * *$ & -5.83 \\
\hline
\end{tabular}




\begin{tabular}{|c|c|c|c|c|}
\hline turn & $-0.019^{* * *}$ & -8.64 & $-0.028^{* * * *}$ & -9.98 \\
\hline Insize & -0.001 & -0.73 & $-0.004 * * *$ & -2.80 \\
\hline Incflow & $-0.002 *$ & -1.94 & -0.001 & -1.15 \\
\hline Ingovsub & $0.002^{* * *}$ & 4.05 & $0.005^{* * *}$ & 8.05 \\
\hline Constant & 0.100 & 5.16 & $0.123^{* * *}$ & 5.07 \\
\hline Year & Yes & & Yes & \\
\hline Number of obs & 782 & & 1679 & \\
\hline R-squared & 0.246 & & 0.203 & \\
Note: *** $p<0.01, * * p<0.05, * p<0.1$
\end{tabular}

From the above empirical analysis, we can conclude that: equity pledge does have a negative impact on the innovation performance of enterprises, when a listed company to carry out equity pledge behavior, itself shows that the company is facing financial pressure, the urgent need for external capital turnover, to the market to send a negative signal, so that the company's share price is facing the risk of decline, In turn, it may lead to a chain reaction to the company in a difficult situation, and the higher the pledge ratio, the greater the enterprise's capital gap, company will have motive to ignore the high investment of innovative research and development, the innovation performance will have a great impact; And what is different is that in companies with high equity concentration, equity pledge has less negative impact on research and development investment, the result is contrary to our initial assumptions. As for the $\mathrm{H} 3$, the empirical results of this paper show that in manufacturing enterprises, compared with non-state-owned enterprises, the equity pledge behavior of state-owned enterprises has a greater impact on the investment of research and development of enterprises. Therefore, the impact of equity structure on enterprise innovation, in the case of equity pledge, the results will be different, the results of this research can provide reference about business behavior and decision-making behavior for company which have the equity pledge behavior.

\section{CONCLUSIONS AND DISCUSSION}

When an enterprise carries out equity pledge, it should consider the market influence and the utilization of the funds obtained from the pledge, and keep the pledge proportion low, so that the necessary funds can be obtained reasonably without affecting the research and development investment of the enterprise. And the equity structure as the basis of corporate governance should have scientific design. The research of this paper shows that the company with high equity concentration has less impact on the innovation of the enterprise, but the absolute concentration of equity design is certainly not favorable to the development of the company. Having scientific design of equity structure, so that the company's shareholders do not appear no one to decide the board, nor the emergence of a single shareholder threat other shareholders, to maintain a moderate concentration of equity, So that it is within a reasonable threshold, so that shareholders can not only consult and make decisions on such a major event as innovation research and development, but also can be properly supervised and controlled, improve the company's innovation research and development output level.

From the empirical analysis results, it can be seen that the results of the last two hypotheses in this paper are inconsistent with the theoretical hypothesis at the beginning of the period, as the results of the existing literature research report say, the nature of equity and the degree of equity concentration will have an impact on the investment in research and development of enterprises, but the conclusions of the study have not been unified. This may be due to the different samples selected and the difference in method usage. The empirical part of this paper still needs to be improved, in the construction part of the model can continue to deepen, for the grouping method, the next study may consider the threshold regression to specifically examine the relationship between equity concentration in different ranges of equity pledge and research and development investment.

\section{REFERENCES}

[1] [1 Zhou Chenxi. Major shareholder equity pledge on the impact of enterprise innovation Research .University of Nanjing,2018.

[2] [2] Zhang Ruijun, Xu Xin, Wang Chaoen. Major Shareholder Equity Pledge and Corporate Innovation . Audit and Economic Research,2017,32(04):63-73.

[3] [3] Wang Fen. Equity Characteristics, Cost Stickiness and Company Innovation Investment .Communication Of Finance And Accounting,2018(21):94-99+129.

[4] [4]Federico Munari,Raffaele Oriani,Maurizio Sobrero. The effects of owner identity and external governance systems on R\&amp;D investments: A study of Western European firms. Research Policy,2010,39(8)

[5] [5] Ren Haiyun, An empirical study on the relationship between equity structure and the investment relationship of enterprise R\&D - Data analysis based on A-share manufacturing listed companies .China Soft Science,2010(05):126-135.

[6] [6] Tang YeGuo, Study on the Promotion effect of equity structure on technological innovation input-Empirical evidence from small and medium-sized listed companies in China. Dongyue Tribune,2013,34(04):105-109

[7] [7] Li Chuntao, Song Min. Innovation Activities in China's Manufacturing Enterprises: Ownership and the Role of CEO Incentives Economic Research Journal,2010,45(05):55-67.

[8] [8] Yang Jianjun, Wang Wei, Sun Fengwen. A Review of the Relationship between Major Shareholder Control and Technological Innovation. Science and Technology Management Research,2014,34(04):204-210.

[9] [9] Wang Huacheng, Hu Guoliu. The Relationship between Equity Structure and Corporate Investment Diversification: Theory and Empirical Analysis. Accounting Research,2005(08):56-62+96.

[10] [10]Suk Bong Choi,Byung Il Park,Paul Hong. Does Ownership Structure Matter for Firm Technological Innovation Performance? The Case of Korean Firms. Corporate Governance: An International Review,2012,20(3).

[11] [11]Deng Z, Peter H, Alexander N. Ownership concentration and product innovation in Chinese private SMEs. Asia Pacific Journal of Management, 2013, 30( 3) : 717-734.

[12] [12]Baysinger BD,Kosnik RD,and Turk TA. Effects of board and ownership structure on corporate strategy,Acdemy of Management Joumal,1991,334(1):205-214. 